THURSDAY, DECEMBER II, I 884

\section{HEALTH LABORATORIES AS THE RESULT} OF THE HEALTH EXHIBITION

MEN of science have thus far regarded the South Kensington Exhibitions of the last two years with very languid interest, if not with some suspicion. There has been throughout some show of scientific intent and much promise of serious result. Needless to say, however, that in regard to the Fisheries Exhibition, whatever may be in store for the future, very little of what was promised of solid or scientific result has thus far been definitely realised. That Exhibition achieved a certain success in technical interest and much was hoped in financial result, but there has been a remarkable reticence in respect to the surplus obtained and its proposed disposal. Little, if anything, has been announced in reply to the urgent requests that have been put forward for information on this subject as to the promotion of new knowledge which should aid the protection of the harvest of the sea, or help to give us information, of which we stand sadly in need, as to the best means of favouring the growth and hindering the destruction of the marine staple of food. So far the Marine Biological Association, which has been started by voluntary effort, has not received any promise of or share in the large sum of money which must now be standing to the credit of the Fisheries' Council. That body are in the happy position of having a continuing receipt as lessors of the buildings just vacated by the International Health Exhibition; they will receive a handsome sum for the next two years at least, and probably also in the succeeding years, from the Exhibitions already planned and in course of arrangement. They have a future before them rich in golden promise, and it is much to be hoped that they will not be unmindful of the new Marine Association. The Council of the International Health Exhibition have been more prompt in declaring the results of their work and in announcing some of its probable issues. Of this Exhibition also it was said, while its doors were open, that the element of display and of public attraction appeared to be much more prominent than did the scientific and solid objects which the great body of busy chemists, sanitarians, and engineers were summoned to assist by their work on the General Committees and on the juries. It will be found, however, by the statement which Mr. Ernest Hart makes in another column of the work done and the results achieved, that, although the serious side of the Exhibition was much less a subject of comment than its more entertaining features, the Council have steadily held the former in view and are likely still to do so in the proposed disposal of the surplus in promoting solid objects of national importance. In this Exhibition for the first time the Council went outside the ordinary routine of exhibits obtained from commercial or speculative sources, and at their own cost brought together and created departments of which the object was purely educational. Thus on the sanitary and unsanitary houses there appears to have been expended nearly $1000 l$., and probably much more than that on the literature of the Exhibition, including a considerable series of hand-books by skilled persons, devoted to

VoL. $x \times x 1 .-$ No. 789 the popular exposition of pubiic and private hygiene, and the reports of conferences and lectures. A library was brought together of sanitary and educational worksabout five thousand in number. Although far from complete, it was in many departments, especially in those relating to civic, official, and foreign sanitation, more extensive than any that had yet been collected. Of this an excellent printed catalogue was prepared, which is of itself a useful book of reference. Besides this, and perhaps far more important, was the creation of two health laboratories, under the direction of Profs. Corfield and Cheyne. By special application to the French Government a full exhibit was also obtained, illustrating the nature of the work and showing the instruments employed by M. Pasteur and M. Mique in their respective institutes. It is well known that laboratories of this kind are especially important for the scientific study of the bacteriological problems which have to be worked out, and which form the basis of the most important public health researches of the present day. The scheme which was presented to the Council in the early days of its work for the formation of these laboratories contemplated the creation of temporary laboratories, which should be put in working order and should demonstrate the nature of the work carried on in such laboratories, and its close and immediate connection with the interests of the health of man, and with investigations of high commercial value to every department of agriculture, and with the study of the costly epizootics which affect the prosperity of the grazing interest and influence of the food-supply of the nation. These laboratories have been in every sense successful. We have already noticed with satisfaction the paragraph in the report which the Council presented on the closing day of the Exhibition, in which they referred to a proposition that had been laid before them for establishing these health laboratories on a permanent footing as the best possible application of the surplus. The amount of that surplus has not yet been determined, and it is premature to speculate upon it. There is reason to fear that it will be much less than has been publicly rumoured. We have seen it anticipated in print that it will amount to nearly $30,000 \%$. On the other hand, we have it on good authority that it is not likely to exceed half that sum. However this may be, it is satisfactory that the address, of which we print a part, and which has a semi-official value, coming from a member of the Executive Council, with the Chairman of the Council presiding, adverts to this application of the surplus almost as though it were a settled matter. Mr. Ernest Hart may of course speak with some excessive hope, inasmuch as it is known that the first establishment of these laboratories was due to his efforts, and they were formed upon the scheme which he drew up for the purpose. The proposition for making them permanent proceeds comes also from him, and no doubt he has a paternal hopefulness which may be excessive. There is, however, evident reason for accepting this most desirable application of the funds as the most probable issue, seeing that the Duke of Buckingham so heartily indorsed it in his speech at the Society of Arts at the close of the address, and that Sir Frederick Abel, also a member of the Exhibition Council, and not likely to speak with other than official caution, stated that Mr. Hart's scheme had now obtained, 
he believed, a pretty unanimous consensus of opinion in the Council. Outside, opinion has at once declared itself with strong approval of this application of the funds, and it is indeed evident that, if the Council can succeed in establishing health laboratories which shall find for the health students of this country establishments properly equipped such as those of Pasteur, Koch, and Miquel, the Exhibition will not have lived its short life in vain, but will leave behind it an institution not only of permanent value but of growing importance and of large promise. The Commissioners of $\mathrm{I} 85 \mathrm{I}$ will certainly see with great satisfaction this liberal intention of the Executive Council of the Health Exhibition to add to those laboratories which they have already provided one which is so greatly needed to complete the means of study and of education which South Kensington supplies in other departments of technical and biological research and teaching. They will probably make no difficulty-or, rather, they will have the strongest reason which a desire for national usefulness will give them to overcome any difficulty-in providing a suitable site for such laboratories. Even if the means which the surplus may provide should not be adequate for the establishment and endowment of such a laboratory, there is little doubt that, with this good beginning, so much may be effected as will afford the best possible reason and the largest inducement to societies such as the Royal Society, the British Medical Association, the British Association, and others to make grants to students conducting rescarch in the laboratories. The Government can hardly refuse to make grants in aid of an institution which in any other country than this would be wholly supported by State funds-witness the health laboratories of France and Germany, which are liberally maintained by State endowments. In this country, however, we are accustomed to look to private entcrprise, and the liberality of societies or committees, to furnish at least a large part of the funds required for scientific research or endowment, and it is satisfactory to know that the Council of the lnternational Health Exhibition have favourably considered the proposition that they should takc the first step in this useful direction. Every one interested in the promotion of real health-progress will trust that it will soon be an accomplished fact.

\section{THE BUTTERFLIES OF EUROPE}

The Butterfies of Europe. Described and Figured by Henry C. Lang, M.D., F.L.S., \&c. Pp. 396, Super-Royal 8vo, with 77 Chromo-lithographic Plates. I88I-I884 in parts. (London : L. Reeve and Co., I884.)

FOR some years past the writer of this notice has, almost annually, formed onc of the members of that large class of Englishmen who, each year, spend a few weeks in the Alpine and sub-Alpine districts of Europe for "relaxation." The writer prefers to leave it to the taste and fancy of the individuals interested to define the meaning of the latter term. He has naturally met hosts of "foreigners" of different nationalities engaged in the same pursuit. Whatever may be the state of the weather or other conditions incidental to travelling of this kind, those voyageurs of Gallic origin succeed in amusing them. selves after their own special fashion. The Teutonic element also succeeds, but in an entirely different manner. The Americans seem tolerably successful. They leave home to "do" Europe, and they "do" it, in their own businesslike fashion,--business and pleasure are carried out on the same principles. Then there comes the large class of our own countrymen and countrywomen. We must confess that, according to our observation, the majority of these do not bear the outward appearance of enjoyment (especially the male portion). There is something apparently wanting. They have left their business or profession behind them, and the void thus occasioned cannot be satisfactorily filled in. From these must, of course, be separated those who find enjoyment in the excitement of Alpine climbing, and some others. Amongst thesc others are those who may be seen with vasculum at back, or insect-net in hand (very frequently in ill-disguised clerical garb), enjoying themselves to an extent unknown to, and often not understandable by, their fellow-countrymen who have voluntarily placed themselves under the same conditions. Probably a still larger amount of Teutons may be observed provided in the same way. And only this year we found ourselves seated next to a New England divine and his wife, and overheard the latter read out to her husband an advertisement of a butterfly-book, with the remark, "That would just suit you."

In the foregoing notes we have tried to draw a picture which we (perhaps we are prejudiced) believe to be tolerably natural. The pursuit of some branch of natural history studies on our travels adds a zest to the other conditions of surpassing value. If pursued systematically, it can hardly be termed "relaxation," if taken to mean "doing nothing." But if the work be harder (and it often is very much harder) than ordinary occupations, it is often the one thing needed, both for health and enjoyment.

Of the bearers of the insect-net in the Alps the majority occupy themselves with butterflies and moths, and the majority of these again with butterflies only. To an Englishman accustomed only to his own meagre, and declining, butterfly fauna, the wealth and beauty of forms is marvellous. With the exception of a small, but useful, manual, published by Mr. W. F. Kirby more than twenty years ago, and which consists almost entirely of laconic descriptions without figures, there has been, up till now, no work in the English language that enables collectors of European (as opposed to British) buttcrflies to name their captures without the troublesome comparison of some noted collection. These therefore will thank Dr. Lang for having supplied the deficiency, and in a generally satisfactory manner. The author has adopted no new system of his own. He follows Staudinger's German Catalogue, describing (for the most part originally) and figuring those species that occur in Europe proper, and simply describing those that have not occurred in "Europe," but still form part of the "European Fauna" (a term becoming daily more difficult to define). We think there is evidence of a little too much dry routine in the text: the descriptions appear to be excellent, and there is always a notice of the larva when known, and tolerably copious geographical information as to distribution, but the class of readers who will mainly use the book would be more readily caught by a mixture of 